\title{
Community-based Approach to Sustain Batik Tourism Village Area in the Special Region of Yogyakarta (The Case of Giriloyo Village)
}

\author{
Anggarani Pribudi \\ Ritsumeikan Asia Pacific University, 1-1 Jumonjibaru, Beppu, Oita, and 874-8577, Japan
}

Email: anggarani424@gmail.com

\section{ARTICLE INFO}

Date received : 17 August 2020

Revision date : 02 September 2020

Date received : 10 September 2020

Keywords:

Tourism Village

Community-based Tourism

Sustainable Tourism Development

\begin{abstract}
The study aims to identify the implementation of Communitybased Tourism to sustain Giriloyo Batik Tourism Village as a sustainable tourism destination. The identification analysis of the Community-based approach is based on thirteen fundamental factors of the ideal Community-based Tourism developed and adopted from related existing literature. This study is a qualitative study with an in-depth interview and a thematic analysis method. The results of the study showed that tourism development began after Yogyakarta's earthquake through supports from NGOs and the Government. Community-based Tourism is implemented which has the characteristics of the thirteen factors of the ideal model of Community-based Tourism I identified. However, there is a difference between the ideal and the fact. The most remarkable gap is in community participation, which in Giriloyo is limited and very active within the Batik Association led by the core members. Stakeholders' roles are crucial in enabling tourism to flourish in Giriloyo Village. The primary stakeholders are Village Government, Local and Regional Tourism Offices Department, and NGOs. Community-based Tourism has positive impacts, mainly in terms of socio-cultural, economic, and environment. Despite the positive impacts, the community is still struggling with several issues, such as regeneration within the organization, domestic waste management, and product innovation.

Concrete efforts are needed to ensure the sustainability of Giriloyo Batik Tourism Village in the long-term.
\end{abstract}

\section{INTRODUCTION}

Sustainability aspects in tourism focus on the future of environmental, economic, and sociocultural impacts concerning visitors' needs, the environment, and host communities (UNWTO, 2013). The UNWTO further elaborates on the critical points in creating sustainable tourism that is maximizing the efficient use of environmental resources while preserving the ecology and nature as well as biodiversity. It also emphasizes on respecting the authenticity, social-cultural value of host communities and contribute to maintaining mutual understanding and tolerance, and lastly to ensure long-term economic and viable operations that benefit all the stakeholders.

Community-based Tourism is an approach that 
aims to create a sustainable tourism destination that focuses on the community's involvement in managing tourism destination. In Indonesia, the tourism industry is one of the leading sectors and players in national economic growth. However, Indonesia still encounters several obstacles such as tourism product management, coordination, and sectoral support that still limits in cross regions because of the ego of regionalism (Yogyakarta, 2014).

Reflecting on tourist's consumption patterns which tend to have a particular interest that is not confined with natural exotica but more in social interactions with the uniqueness of culture and society (Yogyakarta, 2014), the notion of tourism village appears to be an alternative way to link the local community or indigenous community to share their culture with visitors. In Yogyakarta particularly, tourism village development is part of a government's initiative to develop alternative tourism that allows the local community to utilize and expand the applications of available capitals to benefits the local community. Furthermore, tourism village is expected to conserve distinctiveness of the potentials such as local culture and local wisdom that considered to extinct due to globalization (Yogyakarta, 2014).

This study focuses on a case study in Giriloyo Batik Tourism Village in Bantul Regency. Giriloyo Batik Tourism Villages is a union of three sub-villages in Wukirsari Village. The main occupation of the community is Batik artisan spreading in three sub-villages, namely Karang Kulon, Giriloyo, and Cengkehan. Based on the village profile (Desa Wisata Batik Giriloyo, 2016), there were around 725 Batik artisans in the village. Currently, referring to the latest annual report (Paguyuban Batik Giriloyo, 2018) the number of artisans has a significant increase with approximately 1,000 people. It makes Giriloyo village is one of the centers of Traditional Handwriting Batik that still preserves the traditional way of the Batik-making process in Yogyakarta. Batik is one of the prominent cultural heritages of Indonesia that nominated by UNESCO as A Masterpiece of Oral and Intangible Heritage of Humanity in 2009 (Frictions, n.d.). Batik is a traditional fabric made by painting wax called 'malam' and processed in a certain way. Batik is a combination of arts and crafts and has a meaningful philosophy and historical value.

At the beginning of tourism development, a Community-based approach was slowly implemented by the community to manage tourism destination in Giriloyo village. This approach emphasizes the role of the host community to administer and take control of tourism activities in Giriloyo village as well as utilize the available resources. To acquire a deep understanding of how effective Community-based Tourism as a tourism development strategy, it is important to know how the community implements the approach, the crucial elements of it, and to what extent it has been implemented towards the ideal model based on Community-based Tourism factors. It also identifies the importance of stakeholders' roles in Communitybased Tourism and its contribution to tourism development in Giriloyo Batik Tourism Village. Moreover, this study will determine how Communitybased Tourism can sustain Giriloyo Batik Tourism Village as a sustainable tourism destination based on three fundamental principles (socio-cultural, environmental, and economic).

\section{THEORY}

\section{Tourism Village}

Tourism village is defined as a rural area that has distinctive features (physical, natural, social, and cultural), which are managed with supporting facilities in harmonious order and proper management. Tourism village also interlinks with rural tourism which means tourism activities that take place within the capacity of the rural area or countryside to satisfy the needs of visitors (Lane, 2009). Rural tourism focuses on the interplay between 'nature' (as characterized by the physical environment or natural landscapes) and 'culture' (as portrayed by tradition, ritual, unique livelihood and local wisdom), which the practice served by utilizing the critical element of the rural destination that attracts visitors. Tourism Village also means where the small groups of visitors stay in or near traditional, often remote villages and learn about the village livelihood and the local environment (Yogyakarta, 2014). In Yogyakarta particularly, tourism village development is a government policy to develop alternative tourism by utilizing all possible resources and entities that exist in the village in a sustainable way that benefits its community. This policy is based on sustainable tourism development with an approach to Community-based Tourism.

\section{Community-based Tourism}

Community-based Tourism is tourism that involves a community that occurs in their land and based on cultural or natural resources found in their area (Akunaay, Nelson, \& Singleton, 2003). It also may be viewed by adopting an ecosystem approach, where visitors interact with local living (host communities, services) and non-living (landscape, sunshine) to experience a tourism product (Murphy, 2014). According to (Salazar, 2012), Community-based Tourism focused the project and the products on a local community (natural and cultural heritage), which also means tourism that centered on the community's involvement to manage the sites. (Goodwin \& Santilli, 2009) concluded that Community-based Tourism is tourism owned or directed by 
communities and intended to deliver more extensive community advantages, benefit more expansive groups than those employed in the initiative. In brief, Community-based Tourism centers in the community's involvement in managing tourism destinations in their area and creates benefits from it.

Since each community has its characteristics and condition, it is hard to determine the universal model of Community-based Tourism that can be implemented in all types of communities (KARACAOĞLU \& Birdir, 2017). However, Community-based Tourism is considered a successful model if it meets specific factors. Derived from five different sources, Community-based successful factors can be classified into 13 factors.

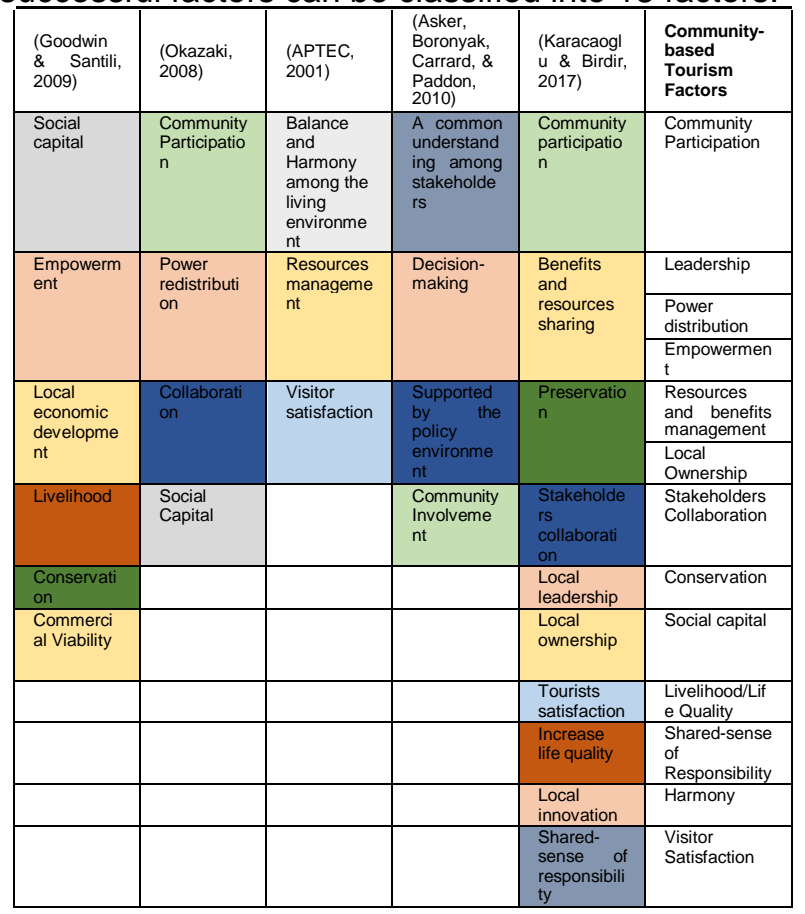

Fig. 1. The Community-based Tourism Factors as Successful Model

Further, each factor is developed into indicators to identify how ideally Community-based Tourism should be applied in Tourism Development and find a gap between the ideal model and the real model on the case study.

\begin{tabular}{|c|c|}
\hline Factors & Indicators \\
\hline $\begin{array}{l}\text { 1. Community } \\
\text { Participation }\end{array}$ & $\begin{array}{l}\text { a. Community members involved in all stages of planning, } \\
\text { embracement, implementation, and evaluation of } \\
\text { Community-based Tourism } \\
\text { b. Community members participated in the decision-making } \\
\text { process for tourism development } \\
\text { c. Community members are allowed to express their opinion } \\
\text { and share ideas and knowledge with others }\end{array}$ \\
\hline 2. Leadership & $\begin{array}{l}\text { a. Leaders manage and direct tourism development and build } \\
\text { relationships between the community members and other } \\
\text { stakeholders } \\
\text { b. Leader push community members to involve in the decision- } \\
\text { making process }\end{array}$ \\
\hline 3. Power Distribution, & $\begin{array}{l}\text { a. Leader distribute certain positions in structured management } \\
\text { b. Leader implement the plans }\end{array}$ \\
\hline
\end{tabular}

\begin{tabular}{|c|c|}
\hline 4. Empowerment & $\begin{array}{l}\text { a. Leader encourages the community to share their ideas and } \\
\text { innovation for the betterment of the tourism village }\end{array}$ \\
\hline $\begin{array}{l}\text { 5. Resources and } \\
\text { benefits management }\end{array}$ & $\begin{array}{l}\text { a. Community members accumulate their resources for } \\
\text { Community-based Tourism is efficiently implemented } \\
\text { b. Community members allocate their resources such as time, } \\
\text { workforce, and money to support Community-based } \\
\text { Tourism } \\
\text { c. Community members allocate a portion of their income } \\
\text { from tourism as a fund for a project that benefits the } \\
\text { community } \\
\text { d. Community members exchange their skills and knowledge } \\
\text { for tourism village development }\end{array}$ \\
\hline 6. Local ownership & $\begin{array}{l}\text { a. Community members have ownership of cultural and } \\
\text { natural resources, which are the major touristic factors } \\
\text { b. Community members actively take place in the tourism } \\
\text { industry, not only as employees but also as } \\
\text { owning/managing the shops }\end{array}$ \\
\hline $\begin{array}{l}\text { 7. Stakeholders } \\
\text { Collaboration }\end{array}$ & $\begin{array}{l}\text { a. There are collaborations between the community and other } \\
\text { stakeholders who have an impact on tourism planning, } \\
\text { policies, and developments } \\
\text { b. Community builds partnerships with stakeholders such as } \\
\text { local governments, the private sector, NGOs, universities, } \\
\text { etc. } \\
\text { c. Stakeholders help the community in developing the } \\
\text { infrastructure, marketing, and promotion of tourism village }\end{array}$ \\
\hline 8. Conservation & $\begin{array}{l}\text { a. Community members particularly aware of the importance } \\
\text { of conservation of environmental and cultural resources in } \\
\text { ensuring sustainable development } \\
\text { b. Community has any preservation projects regarding } \\
\text { environmental resources }\end{array}$ \\
\hline $\begin{array}{l}\text { 9. Social capital } \\
\text { relationships within } \\
\text { the community }\end{array}$ & $\begin{array}{l}\text { a. Leader build a good relationship with each member of the } \\
\text { community } \\
\text { b. Community members have good cooperation to work } \\
\text { together to create a sustainable tourism village }\end{array}$ \\
\hline $\begin{array}{l}\text { 10. Livelihood/Life } \\
\text { Quality }\end{array}$ & $\begin{array}{l}\text { a. Community-based Tourism has positive impacts on the } \\
\text { prosperity of the village community } \\
\text { b. Community-based Tourism has implications on improving a } \\
\text { better livelihood } \\
\text { c. Community-based Tourism triggers local economic } \\
\text { development }\end{array}$ \\
\hline $\begin{array}{l}\text { 11. Shared-sense of } \\
\text { Responsibility }\end{array}$ & $\begin{array}{l}\text { a. Community members accept shared responsibility for the } \\
\text { development, organization, and management of the } \\
\text { Community-based Tourism activities that aim to increase } \\
\text { prosperity, including cultural and environmental resources } \\
\text { b. Each member understands the importance of his/her role in } \\
\text { sustainable development progress } \\
\text { c. Each member take responsibility to minimize the negative } \\
\text { impacts on the socio-cultural environment } \\
\text { d. Each member rapidly take precautions to eliminate the } \\
\text { deterioration and depletion problems of the cultural and } \\
\text { natural resources }\end{array}$ \\
\hline 12. Harmony & $\begin{array}{l}\text { a. The community can develop a sense of community and } \\
\text { purposefulness in life } \\
\text { b. Ability to respond to increasing tourism demands } \\
\text { c. Community revitalization through resource use } \\
\text { d. Tourism promotion through harmony with local value and } \\
\text { the living environment }\end{array}$ \\
\hline 13. Visitor Satisfaction & $\begin{array}{l}\text { a. Community is less to accept complaints regarding service } \\
\text { from the visitors } \\
\text { b. The community received positive feedback from visitors } \\
\text { c. There are repeated visitors } \\
\text { d. There is a significant number of visits }\end{array}$ \\
\hline
\end{tabular}

Fig. 2. The Community-based Tourism Factors and Indicators

\section{Sustainable Tourism Development}

Several scholars have their definition of sustainable tourism. (Archer, Cooper, \& Ruhanen, 2005), saw sustainable tourism on the linkage between economic and the environment, while (Butler, 1999) defined sustainable tourism within three main areas (environmental, socio-cultural, and economic) and included the term of carrying capacity. Sustainable tourism, according to (Lane, 1994), is a triangular relationship between people, their host areas and habitat, holidaymakers, and the tourism industry. (Lane, 1994) further explained that this concept aims to reconcile the three partners in 
the equilibrium for the long term. He also suggested that sustainable tourism should diminish the environmental and cultural damage, optimize visitor satisfaction, and long-term economic growth within the region (Lane, 1994). In more detail, the UNWTO described sustainable tourism as tourism that is responsible for its current and future economic, social and environmental impacts, addressing the demand of visitors, the industry, the environment and host communities (UNWTO, 2013). The primary purpose of Community-based Tourism implementation is ensuring the sustainability of tourism destinations based on three pillars of sustainability.

\section{METODE}

This study is qualitative field research based on a case study in Giriloyo Batik Tourism Village. The case study is an in-depth identification that focuses on a single social phenomenon (Babbie, 1989). This study aims to explore the tourism development through Community-based Tourism in Batik Tourism Village and its impacts in creating a sustainable tourism destination from the perspective of the host community. Data collection methods primarily used in-depth interviews with the community. The interview results contain descriptive data. To ease in sorting the information to answer the research question, a thematic analysis used in analyzing the data. Thematic analysis is described as an independent qualitative descriptive approach to identify, analyze, and reporting patterns or themes within the data (Braun \& Clarke, 2006).

\begin{tabular}{|c|c|c|}
\hline & Phases & Description of Analysis Process \\
\hline 1 & $\begin{array}{l}\text { Data } \\
\text { Collection }\end{array}$ & 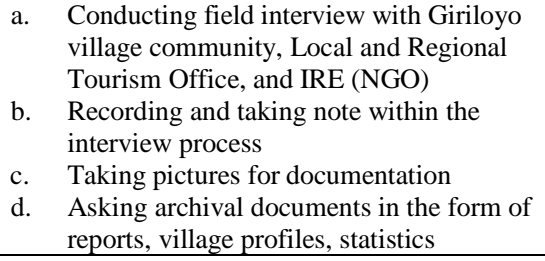 \\
\hline 2 & $\begin{array}{l}\text { Data } \\
\text { Managing }\end{array}$ & $\begin{array}{l}\text { a. Transcribing interview data from the } \\
\text { recording }\end{array}$ \\
\hline 3 & $\begin{array}{l}\text { Familiarization } \\
\text { and Coding }\end{array}$ & 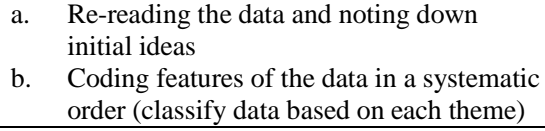 \\
\hline 4 & $\begin{array}{l}\text { Reviewing } \\
\text { themes }\end{array}$ & $\begin{array}{l}\text { a. Reviewing data for additional theme } \\
\text { b. Defining the pattern in each theme } \\
\text { c. Generating a thematic 'map' of the } \\
\text { analysis }\end{array}$ \\
\hline 5 & $\begin{array}{l}\text { Defining } \\
\text { themes }\end{array}$ & $\begin{array}{l}\text { a. Refining the specifics in each theme and } \\
\text { the overall story } \\
\text { b. Generating clear definitions in each theme }\end{array}$ \\
\hline 6 & Report & $\begin{array}{l}\text { a. Relating the analysis to research question, } \\
\text { objectives, and literature } \\
\text { b. Narrating the results of the final analysis }\end{array}$ \\
\hline
\end{tabular}

Fig. 3. The Thematic Analysis Process

\section{RESULTS}

Tourism Development in Giriloyo Batik Tourism Village

Tourism development in Giriloyo initially began when an earthquake hit Yogyakarta and destroyed the whole village in 2006. In 2007 - 2008, the stakeholders helped the community to rebuild the village and recover from trauma. In between those years, the community received help from stakeholders (NGOs and government) that covered infrastructures, human resources development (training and capacity building), tools and materials, and financial capital as well. The community started to hold a gathering and forming small groups of Batik artisans (currently 13 groups) and united all groups in one organization called 'Paguyuban Batik Giriloyo' or Giriloyo Batik Association.

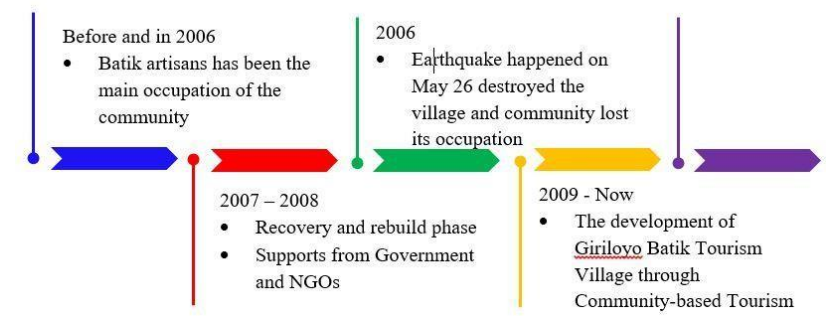

Fig. 4. The Chronological Order of The Establishment Giriloyo Batik Tourism Village.

\section{Community-based Tourism Implementation Model Community Participation}

The primary actors in the Giriloyo batik Tourism Village are Batik artisans, predominantly women (homemakers and older people). Community participation in Giriloyo Batik Tourism Village can be divided into two terms (organization at the community level in Giriloyo and village level). In a tourism village, the organization has a vital role in managing tourism activities. Due to the difficulty of involving all community members to participate within the core management of the Association, all stages of planning, embracement, implementation, and evaluation regarding tourism village are discussed within the forum that held once in a month. The decision-making process is determined by voting and consensus among members. However, all members (all batik artisans) are allowed to express and share their opinion, idea, critique, and evaluation of tourism activities. Members can share it through their group, and the representative will deliver the opinion to the core management in the Association.

\section{RESULTS AND DISCUSSION}




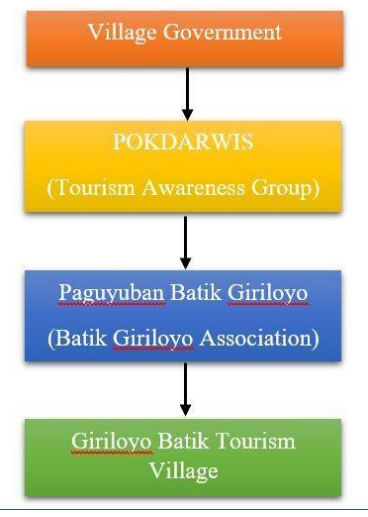

Fig. 5. The Hierarchy of Organization in Giriloyo Batik Tourism Village

\section{Leadership}

There are two leaders (Head I and Head II) in the organizational structure. Leaders are responsible for leading and directing members in tourism activities, building a partnership with stakeholders (Village, Government, and NGOs), embracing and encouraging all community members to actively participate in tourism, contributing through innovation and ideas as well as determining all crucial decisions within the organization. The heads of the Association are chosen by the community through voting in the forum. In some cases, the village government, as an advisor, also has the authority to recommend candidates as the heads of the Association if the community cannot find any eligible candidates. Since leaders have important duties and responsibilities, it is difficult to nominate leaders candidates in the Association that make it more challenging to have leaders regeneration. In the association, leader candidates are expected to volunteer out of willingness rather than appointed by the community members. If there is no volunteer, the community usually recommends the heads of the sub-villages to be candidates.

\section{Power Distribution}

Technically, the power is distributed into certain positions within the organizational structures in Batik Giriloyo Association. the organization also involved external parties from the village government, local elites (prominent figures in the community), and NGOs as supervisors and advisors. The decisionmaking process is determined within the forum and agreed by all respective members of the organization (the core management). Concerning the implementation of the plan that has been made within the forum depends on the priority. The organization has the main authority in distributing power, including information and access regarding tourism. However, there is no fully centralized authority, which means the organization allows each group to expand and promote its products outside the association.

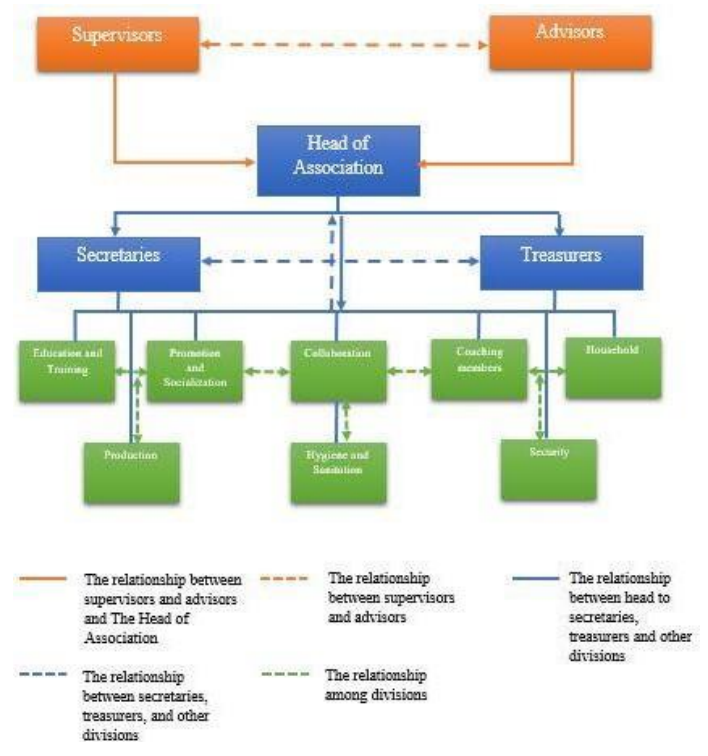

Fig. 6. The organization structure of Batik Giriloyo Association

\section{Empowerment}

In terms of empowerment, most of the Batik artisans in Giriloyo are predominantly women who are mainly housewives and the older generation. They take part as tutors or guides in Batik learning activities. To become a tutor, artisans have to participate in training that trains them about how to explain and guide the visitors and even public speaking. To enhance the capacity of Batik artisans, the Association often sends its members to join the education and training program held by the government institution such as the Batik design workshop, entrepreneurial seminar, creative industry workshop, and so on.

\section{Resources and Benefits Management}

In terms of resources and benefits management, the main products in Giriloyo are Edutourism Batik (Batik-making learning) and Batik products. Edu tourism depends on the Batik learning package chosen by visitors. The primary allocation for Edu-tourism is workforce and time, predominantly done by women as tutors. Tutors are not paid monthly. They will be paid on the same day when they finished their work. The second benefit is from Batik Products (fabric and other souvenirs). Each Batik fabric that sold will be cut $20 \%$, for Batik association income $(3 \%)$, the salesperson on the day $(7 \%)$, and other commissions (10\%).

\section{Local Ownership}

The primary resources of Giriloyo Village are land, the Gazebo Batik, and Group workshops. Gazebo Batik is a shared-ownership among the community in Giriloyo Batik Tourism Village in which the Village Government provides the land. The 
Gazebo Batik is the place where most of the tourism activities are taken place. Despite the artisans can sell their products in the showroom (at the Gazebo complex), the Association allows artisans (accommodated bt their group) to display, sell and promote their products through their shops or workshop.

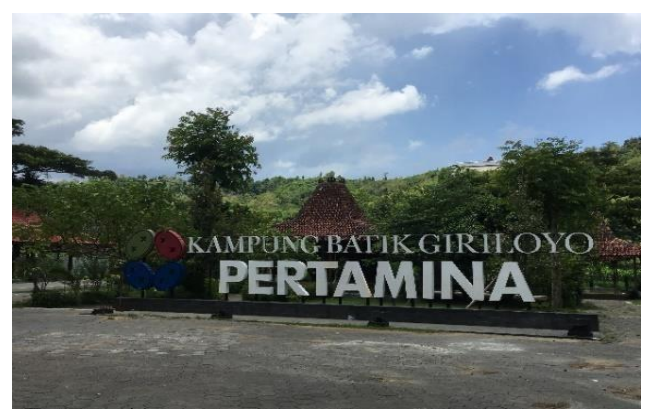

Fig. 7. The Main Gazebo Batik

\section{Stakeholders Collaboration}

Stakeholders play significant roles in community-based tourism implementation in Giriloyo Batik Tourism Village. The Government (Tourism Office Department) and several NGOs such as Institute for Research and Empowerment (IRE), Jogja Heritage Society (JHS), and Dompet Dhuafa are the main stakeholders that support the local community in Giriloyo to initiate Batik Tourism Village. Besides Government and NGOs, universities (Universitas Pembangunan Nasional 'Veteran' Yogyakarta, Gadjah Mada University, Mercubuana University, Sanata Dharma University) also supported the community through research and community services. Stakeholders' aids consist of physical and non-physical supports. Physical covered infrastructures for tourism facilities such as The Gazebo Batik, Parking Field, toilets, prayer room, showroom, fence, and pavement. The nonphysical included capacity building, human resources development, education and training, organizational skills, Information and Technology, promotion and marketing, product development, management, and accounting, as well as financial capital. Some partnerships, such as from Local and Regional Tourism Office Department and IRE, still occur in the form of advisory, monitoring, and evaluation related to the tourism development progress in Giriloyo Batik Tourism Village.

\section{Conservation}

Conservation is divided into two aspects, environmental and cultural. In terms of environmental, the community initiates to make a water waste management system in the form of shelter wells to prevent soil and groundwater pollution from Batik coloring process. The installation consists of up to six wells that each well contain specific substances such as cover alum, palm fiber, sand, and activated carbon. The community is also encouraged to use natural colors such as Indigofera and mahogany which are ecofriendly. Besides, the community also initiates reuse practice for utilizing 'malam'(Batik wax) to be used effectively. In terms of culture, the community committed to preserving the traditional handwriting Batik with a specialty in Mataram's classic design as a valuable heritage as well as conserving Javanese culture. Batik is also introduced as a local content subject in elementary schools so that the younger generation knows the importance of preserving batik as a valuable heritage.

\section{Social Capital}

Social Capital emphasizes on the network or relationship among community members that enable the community to function effectively, while community participation emphasizes the community's active involvement in the decisionmaking process. Social capital in Giriloyo Batik Tourism village is shaped in the joint-venture spirit in the form of the Batik Giriloyo Association. There are approximately 1000 Batik artisans (Paguyuban Batik Giriloyo, 2018), who affiliated in 13 Batik Groups and united within the Association. The Association serves as a place where community members can communicate together in one forum. Communication is the crucial point to maintain a good relationship among community members. Community in Giriloyo maintains communication in three ways through social gatherings, monthly forum meetings, and online group via social media. These methods are quite useful in sharing and communicating with the village's community.

\section{Livelihood/Life Quality}

In terms of livelihood and the improvement of life quality. There are significant differences after community-based tourism is being implemented within the recovery period. Before the Yogyakarta's earthquake, Batik artisans in Giriloyo were mere laborers. They made half-ready Batik and sold it to the city to be processed into ready products. They had minimal skills and meager income around IDR 50,000 (USD 3.56) and often paid behind the schedule. During recovery, NGOs gave batik artisans training for product development. The training program equipped them with the knowledge to design Batik patterns, coloring techniques, and including product marketing. From the training, their livelihood gradually improved, and they could rebuild their village. In a decade, the community has established Batik Tourism Village and offers Batik learning packages as well as sells its Batik products. The Tourism Village now could generate revenue of IDR. 538,449.500 (USD. 38,329.42) annually from Tourism. Batik artisans can help to 
support their families. They earn income from selling Batik products and as a guide/tutor. The increasing income also affects their health, the level of education of their children, and their social status. They can send their children until university, build a better house, or starting their own business. More importantly, tourism development stimulates the creation of small-medium enterprises and entrepreneurial activity, particularly in the field of the creative industry.

\section{Shared-sense of Responsibility}

Batik Association has created a set of rules in the form of statute/bylaw, duty, and responsibility of each position, and consensus or mutual agreement. These rules serve as guidance for community members in running the organization as well as tourism activities in Giriloyo village. Each member is required to have a strong understanding of his/her roles both as the Association and village community member. Also, Batik Association has a firm principle in teamwork that requires members to help each other regardless of their job position. For instance, if the production division needs help in handling tools and materials, other divisions will come to help and vice versa. Community members who involve in the Batik learning activity are required to understand and apply the precaution acts based on the standard operating procedure. tutors/guides should attend a short briefing to remind the guide/tutors on how to conduct the Batik learning activity in safety procedures. Community members bear full responsibility for the accidents that occur during the tourism activities in the Gazebo Batik. Hence, the safety procedure is a vital aspect that needs to be understood and applied by community members.

\section{Harmony}

Harmony is the relationship between the host community, the environment, and visitors. In Giriloyo, most of the residents work as Batik artisans. As community members share the same source of livelihood, it creates a sense of community and purposefulness of life. The sense of community is the root of establishing the Association with a joint venture spirit in the field of tourism. In fostering harmony, tourism promotion should emphasize the local value and living environment. It means that promotion should go along with the local value and tradition of the community and their living environment.

\section{Visitor Satisfaction}

Visitor satisfaction is primarily reviewed from the perspective of the host community, reflecting on the impression of the visitors after experiencing in making Batik. Since the tourism package in Giriloyo focuses on Batik learning, the main visitors are students, from elementary level until university students. Another visitor is usually a group tour. Although there was a considerable increase in the latest three years (Fig. 7), it does not necessarily prove the visitors' satisfaction. The community mentioned that it is quite rare to hear severe complaints from the visitors. Since most of the visitors are coming from outside Yogyakarta, they are quite impressed with learning how to make handwriting Batik. Since the ability to give excellent service and fulfill the demand to the visitors is also essential, tutors/guides emphasize creating a friendly atmosphere where visitors can enjoy making Batik in a more relax and joyful way.

\section{The Number of Visitors in 2016 - 2018}

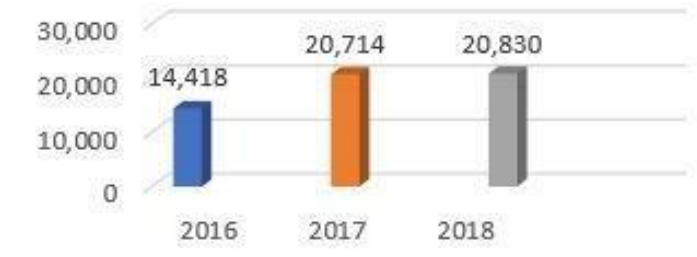

Fig. 8. The Number of Visitors in Giriloyo Village in $2016-2018$

Source: (Desa Wisata Wukirsari, 2019)

\section{Stakeholders Roles in Community-based Tourism}

In Giriloyo Batik Tourism Village, stakeholders hold crucial roles in the implementation of Community-based Tourism. Stakeholders provide supports both physical and non-physical. The main stakeholders are the local (village and regency level) and regional governments, and NGOs. In Giriloyo, the village government facilitates the community in providing some areas of land (village treasury) for tourism facilities such as the Gazebo batik and parking field and in the form of advisory as well. While at the regional level through the Tourism Office, provide monitoring and evaluation regarding the progress of the tourism village. NGOs have important roles in building knowledge through human resources development, such as education and training programs. NGOs also support the community in terms of organizational skills. The organization is vital to start developing tourism villages as the community will manage its resources, create tourism package, and collaborate with other stakeholders.

\section{Impacts of Community-based Tourism in Sustaining Giriloyo Batik Tourism Village}

In terms of socio-cultural, Batik has already existed approximately since the 17th century in Giriloyo. Through tourism village, it reconfirmed Batik as the community's identity and an essential part of their livelihood. Now that Batik has admitted 
as the world's intangible cultural heritage by UNESCO, the community has a sense of responsibility to preserve the heritage and pass it on to the next generation. The community commits to keep the authenticity of Batik Giriloyo, which emphasizes the traditional handwriting technique and Mataram Classic pattern that inherited from their ancestors. In terms of economic, tourism enables the community to offer not only Batik products in which successfully generates income for the community but also traditional knowledge through learning that also generates additional income for the artisans, which they involve as tutor/guide. Tourism village has made a significant effect in increasing revenue and improving the livelihood of Batik artisans. In terms of environmental aspects, tourism raises the community's awareness to keep their business flourishing without damaging their living environment. The environmental awareness led to the initiation of the water waste management system to purify synthetic dyed water from the Batik coloring step so that it will not pollute the soil and groundwater. The community is also encouraged to minimize the usage of synthetic color and to use the natural color from plants, which is harmless for the environment.

\section{DISCUSSION}

Community-based Tourism implementation in Giriloyo Batik Tourism Village was assessed concerning the thirteen factors of ideal Communitybased Tourism. However, in some factors, there are quite significant gaps between the ideal and the reality. Compared to the other factors, Community participation is the most crucial factor that ensures the success of Community-based Tourism practice in the Tourism Village. Community participation can be deemed ideal if all community members participate in all stages of planning, embracement, implementation, evaluation, and decision-making process. Community members are also allowed to express their opinion and ideas. In Giriloyo Batik Tourism Village, the foremost authority in destination management is Batik Association. Although it is difficult to involve all members of the community, the Association is barely changing in terms of staff regeneration. Since the establishment of the Tourism Village, the core members merely exchange positions within the organizational structure. Another problem is the level of interest of young people to involve within the Association is quite low. In Tourism Village, the organization is very pivotal. It serves as a bridge that links the local community to the stakeholders. Currently, Giriloyo Batik Association accommodates more than one thousand Batik artisans, yet they found it is difficult to have staff regeneration.

Regeneration's importance within the organization is undeniably crucial to sustaining the tourism village. The Government's Tourism Office Department stated that a village with tourism potential could not be a tourism village if it does not have a management system in which it is the organization. However, currently, there is no policy or written rules that regulate the term of main staff for the tourism village organization. In Giriloyo, this organizational issue is still unanswered yet. If there is no regeneration within an extended period, there might be a possibility for exclusion towards access. In the case of Giriloyo, the decision-making process is limited within the core management, and the Association is the first party to deal with stakeholders directly. Although, Batik Association is based on the principle of a joint venture, yet, if several people hold the primary access, it does not rule out the possibility for excluding the access from non-active members. Therefore, member regeneration is vital to ensure that other members have the same opportunity to involve directly in managing tourism activities in Giriloyo village. The effectiveness of the organization is still questionable to ensure maximum community participation in Community-based Tourism. Further studies and discussions about related policies and regulations are needed to overcome the issue.

\section{CONCLUSION}

Community-based Tourism implementation in Giriloyo Batik Tourism Village was found to apply the thirteen fundamental factors of the ideal Community-based Tourism. Those factors are, 1) Community Participation, 2) Leadership, 3) Power Distribution, 4) Empowerment, 5) Resources and Benefits Management, 6) Local Ownership, 7) Stakeholders Collaboration, 8) Conservation, 9) Social Capital, 10) Livelihood/Life Quality, 11) Shared-sense Responsibility, 12) Harmony, 13) Visitor Satisfaction. However, in actuality, there is a gap between the ideal and the fact on several elements as well as issues that are still facing the community such as regeneration, organizational transformation, improvement in community's participation, and environmental issue such as domestic garage management. Concrete efforts from the community to solve the current issues are very important in sustaining Giriloyo Batik Tourism Village. Finally, since the study only focuses on a case study, there might be many aspects overlooked during the field research and need to be found and enhance for further research specifically in the field of community-based tourism in the tourism village.

\section{REFERENCES}

Akunaay, Mustapha, Nelson, Fred, \& Singleton, Elizabeth. (2003). Community based tourism in 
Tanzania: Potential and perils in practice. Second Peace Through Tourism Conference, 7-12.

Archer, Brian, Cooper, Chris, \& Ruhanen, Lisa. (2005). The positive and negative impacts of tourism. Global Tourism, 3, 79-102.

Babbie, Earl. (1989). The Practice of Social Research . California: Wadsworth. Inc.

Braun, Virginia, \& Clarke, Victoria. (2006). Using thematic analysis in psychology. Qualitative Research in Psychology, 3(2), 77-101.

Butler, Richard W. (1999). Sustainable tourism: A state-of-the-art review. Tourism Geographies, $1(1), 7-25$.

Desa Wisata Batik Giriloyo. (2016). Profil Desa Wisata Giriloyo Wukirsari. Bantul: Desa Wisata Giriloyo Wukirsari.

Frictions, F. i. (n.d.). Retrieved from Forthcoming in Museum Frictions: Public Cultures/Global .... https://www.nyu.edu/classes/bkg/web/heritage. pdf.

Goodwin, Harold, \& Santilli, Rosa. (2009). Community-based tourism: A success. ICRT Occasional Paper, 11(1), 37.

KARACAOĞLU, Sıla, \& Birdir, Kemal. (2017). Success Factors of Community Based Tourism (CBT) Perceived by Local Peoples:
The Case of $\% 100$ Misia Project. International Rural Tourism and Development Journal (IRTAD) E-ISSN: 2602-4462, 1(2), 53-61.

Lane, Bernard. (1994). Sustainable rural tourism strategies: A tool for development and conservation. Journal of Sustainable Tourism, 2(1-2), 102-111.

Lane, Bernard. (2009). Rural tourism: An overview. The SAGE Handbook of Tourism Studies, 354-370.

Murphy, P. E. (2014). Tourism: A Community Approach. London: Routledge.

Paguyuban Batik Giriloyo. (2018). Laporan Pertanggungjawaban Kegiatan Tahunan Paguyuban Batik Giriloyo Tahun 2018. Bantul. Yogyakarta: Paguyuban Batik Giriloyo.

Salazar, Noel B. (2012). Community-based cultural tourism: issues, threats and opportunities. Journal of Sustainable Tourism, 20(1), 9-22.

UNWTO, E. C. (2013). Sustainable tourism for development guidebook. World Tourism Organization, European Commission, Madrid.

Yogyakarta, G. (2014). (2014). Final Report of Study of Tourism Village Development in DIY (Government). Yogyakarta.

\section{Copyright holder :}

Anggarani Pribudi (2020)

First publication right :

Journal of Social Science

This article is licensed under: 